\title{
Editorial: Livestock Production and the Functioning of Agricultural Ecosystems
}

\author{
Gary S. Kleppel ${ }^{1 *}$, Fred D. Provenza ${ }^{2}$ and Juan J. Villalba ${ }^{2}$ \\ ${ }^{1}$ Department of Biology, University at Albany, Albany, NY, United States, ${ }^{2}$ Department of Wildland Resources, Utah State \\ University, Logan, UT, United States
}

Keywords: livestock management, grazing impacts, health and meat, livestock and social welfare, integrated agriculture

\section{Editorial on the Research Topic}

\section{Livestock Production and the Functioning of Agricultural Ecosystems}

\section{OPEN ACCESS}

Edited and reviewed by: Ivette Perfecto,

University of Michigan, United States

*Correspondence:

Gary S. Kleppel gkleppel@albany.edu

Specialty section:

This article was submitted to Agroecology and Ecosystem Services, a section of the journal Frontiers in Sustainable Food Systems

Received: 01 April 2021 Accepted: 14 May 2021

Published: 21 June 2021

Citation:

Kleppel GS, Provenza FD and Villalba JJ (2021) Editorial: Livestock Production and the Functioning of Agricultural Ecosystems.

Front. Sustain. Food Syst. 5:690016. doi: 10.3389/fsufs.2021.690016
Approximately $37 \%\left(5.1 \times 10^{7} \mathrm{~km}^{2}\right)$ of the Earth's land mass is used for agriculture, but only about $11 \%$ of that is capable of large-scale crop production (World Bank, 2021a,b). As such, about $26 \%$ of the Earth's agricultural land can only be used to produce animals. Despite trends toward veganism in some countries, the consumption of meat is increasing globally, and sustained consumption of the vegan diet is rare (Lal; van Vliet et al.). Although domestication of animals began nearly 11,000 years ago, our species' relationship with livestock has been challenging from the beginning. From the first efforts at domestication to the present day, livestock have been zoonotic disease vectors (Diamond, 1998). Livestock management has challenged the integrity of ecosystems globally (Kleppel; Teague and Kreuter) and has created social, animal welfare and public health concerns in both developed and developing countries. Clearly, the relationship between humans and the animals we raise for food is paradoxical. On the one hand, they are the source of nourishment, particularly protein, for most of the people on this planet. On the other, they and the practices used to raise them are major contributors to the pollution of surface waters, the degradation of air quality, the emission of greenhouse gases, the destruction of soil, vegetation and biodiversity, and the incitement of social unrest. While it is unlikely that any of this would or could compel Homo sapiens to turn again to a hunter-gatherer lifestyle, it is worth considering animal agriculture from both positive and negative perspectives, endeavoring to resolve those aspects of practice that threaten our environment and social systems, and to replace them with beneficial practices and approaches to produce food for a rapidly growing, but endangered human population on this fragile planet.

To respond to this challenge, we have compiled a collection of research and review articles dedicated to the many facets of Livestock Production and the Functioning of Agricultural Ecosystems. In fact, livestock and humans can contribute to meeting such challenges by integrating key principles underlying the adaptive and dynamic interactions of plants, animals, and humans with their environment into existing and novel management practices that foster ecosystem health and biodiversity. The nine papers presented here address the topic from different perspectives, providing readers with a range of questions and challenges associated with animal agriculture. The subjects examined in this issue are wide ranging, from the benefits of nonfiber carbohydrates in forage for beef cattle, to the comparison of different philosophies of pasture and rangeland management, to the resolution of conflicts between herders and crop farmers, as well as herders and lions, to the benefits of an omnivorous over an herbivorous diet. Several themes emerge from this compendium. Pre-eminent among them are the: (i) importance of biodiversity in animal agriculture, (ii) impacts of different management approaches 
to livestock and the environment, and (iii) effects of animal agriculture on human well-being and wildlife conservation. There are numerous overlaps among themes. For instance, biodiverse livestock operations may not only help mitigate certain climate change impacts, but they may increase economic stability, particularly in the developing world.

The theme of biodiversity is central to articles by Lal, Dumont et al., and Rowntree et al., who consider the implications of animal-crop-tree farming, and multi-animal species integration from different perspectives. As Dumont et al. point out, “... the diversity of system components and interactions among these components can increase productivity, resource-use efficiency and farm resilience." These ideas are captured in the life cycle assessment conducted by Rowntree et al. on a farm that practices multi-species rotational grazing in Clay County, Georgia, USA. They are extended further by Lal, who demonstrates the links between integrated agriculture, environmental quality and social well-being within the context of the UN's Sustainable Development Goals.

The second theme, the environmental and nutritional impacts of different management approaches, focuses on forage quality and emerging livestock and grazing-land management approaches. Villalba et al. remind readers of the importance of non-structural or non-fiber carbohydrates in beef cattle nutrition and they recommend the incorporation of such nutritional sources, particularly legumes, into forages for livestock on pasture. Teague and Kreuter, and Kleppel focus on regenerative methods of livestock production. Regenerative agriculture emphasizes soil health and the restoration of ecosystem services. Kleppel compares the environmental impacts of regenerative and conventional animal agriculture, the latter being associated with practices that have become mainstream since the end of World War II. He suggests that relative to conventional practice, regenerative techniques favor restoration and maintenance of environmental quality and ecosystem services. Teague and Kreuter emphasize that, "[s]cientists partnering with farmers and ranchers... who have improved their... resource base and excel financially have documented... sound environmental, social, and economic outcomes."

The third emergent theme in this issue, the effects of animal agriculture on human well-being and wildlife conservation, focuses on human health, and on interactions among disparate

\section{REFERENCES}

Diamond, J. (1998). Guns, Germs and Steel. New York, NY: Norton.

World Bank (2021a). Agricultural Land (\% of Land Area). Available online at: https://data.worldbank.org/indicator/AG.LND.AGRIS.ZS (accessed March 31, 2021).

World Bank (2021b). Arable Land (\% of Land Area). Available online at: https:// data.worldbank.org/indicator/AG.LND.ARBL.ZS (accessed March, 31 2021).

Conflict of Interest: The authors declare that the research was conducted in the absence of any commercial or financial relationships that could be construed as a potential conflict of interest. human communities, and humans and non-humans. van Vliet et al. present a comprehensive analysis of the nutritional importance of the omnivorous human diet, making the case for the synergistic nutritional complementarity of plant- and animalbased foods. They extend the discussion to popular plant-based meat alternatives, showing that extensive processing and lack of animal-based nutrients prevents them from being nutritionally complete substitutes for animal foods. Jablonski et al. describe the resolution of stress between Maasai herders and African lions, caused by increased lion depredation on livestock, by identifying and correcting weaknesses in herding practices. Similarly, Alary et al. document the reduction of stress between Bedouin herders who have long used the western edge of the Nile Delta to graze their livestock and newly arrived farmers seeking to cultivate the land.

Ultimately, this volume speaks to the breadth of researchable questions associated with animal agriculture, the integrated context of thematic areas within the discipline, and the obvious role that livestock production can play, not only in the food supply, but to human health, social welfare, and the future of Earth's ecosystems. Animal agriculture is in a state of transition. Changes are occurring in the ways we manage livestock and produce food and fiber from them. Answers to many of the questions raised in these papers remain elusive. Many will be controversial. But if good research raises more questions than it answers, then this issue should prove a useful stimulus for new research into the 11,000-year old practice of cultivating animals for food and fiber.

\section{AUTHOR CONTRIBUTIONS}

GK, FP, and JV contributed substantively to the production of this document. GK prepared the initial draft of this Editorial. FP and JV reviewed and revised the draft. All authors approved the submitted version of the article.

\section{ACKNOWLEDGMENTS}

We are grateful to the authors who contributed manuscripts to this issue, and to the many reviewers and paper editors, who contributed their time and efforts to ensure the success and quality of the peer review process.
Copyright (๑ 2021 Kleppel, Provenza and Villalba. This is an open-access article distributed under the terms of the Creative Commons Attribution License (CC BY). The use, distribution or reproduction in other forums is permitted, provided the original author(s) and the copyright owner(s) are credited and that the original publication in this journal is cited, in accordance with accepted academic practice. No use, distribution or reproduction is permitted which does not comply with these terms. 